\title{
ANALISIS PENGARUH \\ INFLASI, TINGKAT SUKU BUNGA SBI DAN NILAI TUKAR TERHADAP JUMLAH UANG YANG BEREDAR DI INDONESIA \\ Periode 2001 s/d 2006
}

Oleh:

Indah Yuliana*)

\begin{abstract}
There are many macro economic indicators which is usually used to measure wheel growth of state, for example that is inflation, exchange rate, rate of interest storey; level and also the amount of money supplies in state. Distortion movement of difficult exchange rate in order to be known and forecasted. it exchange rate very base on various factor, among others that is moneys amount and inflation circulating. Moneys amount circulating by relative influence exchange rate. Whether in home affairs and in international world. A currency will decrease the value of if moneys amount circulating more. Each there is sign indicating that the amount of moneys circulating to grow swiftly hence surely the money available in number many and the him of declining. Strength of economics fundamental a state in emulation in world market reflected to through dealt only with state currency value is other state. If real sector can print surplus to trade partner state, relatively will strengthen and improve currency value and if real sector asset productivity not optimal hence balance of trade and transaction will experience of deficit. This influence exchange rate depressions, so that have no other way to except isn't it currency on the chance of domestic product competitiveness can mount sold cheaper product to global market. This Research target is first is to see influence of inflation, rate of interest storey; level of SBI and exchange rate by simulate to moneys amount circulating in Indonesia, secondly is among inflation, rate of interest storey; level of SBI and exchange rate, which was which is dominant of influence of to moneys amount circulating in Indonesian. Analyzer the used is doubled linear regress. This Research result is (1) By simulate inflation, level of SBI and exchange rate have an effect on to moneys amount circulating in Indonesia period 2001 to 2006. (2) Variable mount rate of interest of SBI is dominant Variable of influence of to moneys amount circulating in Indonesia period 2001 to 2006.
\end{abstract}

Keyword: Inflation, level of SBI, exchange rate and moneys amount circulating.

\section{PENDAHULUAN}

\section{Latar Belakang}

Masuknya globalisasi di bidang ekonomi dan informasi tidak dapat dihindari, begitu juga dengan pasar keuangan. Kemajuan tehnologi serta adanya komunikasi yang semakin cepat mendorong terjadinya integrasi pasar-pasar keuangan di seluruh dunia ke dalam pasar keuangan internasional. Kemajuan tehnologi dan adanya komunikasi yang semakin cepat mendorong terjadinya integrasi pasar-pasar keuangan di seluruh dunia ke dalam pasar keuangan internasional. Kemajuan sistem telekomunikasi yang menghubungkan secara 
langsung pelaku pasar di seluruh dunia. Transaksi dapat dilakukan tidak hanya dalam hitungan hari atau jam tetapi sudah menit, bahkan detik. Melihat fenomena yang demikian itu perusahaan multinasional berusaha memperoleh dana dari pasar valuta asing. Pasar valuta asing adalah suatu mekanisme di mana orang dapat mentransfer daya beli antarnegara, memperoleh dan menyediakan kredit untuk transaksi perdagangan internasional, dan meminimalkan kemungkinan resiko kerugian akibat terjadinya fluktuasi kurs suatu mata uang (Siamat,1999: 228). Pasar valutra asing ini menjangkau seluruh bagia dunia, dimana harga-harga mata uang senantiasa bergerak setiap saat. Harga dari satu mata uang dalam mata uang lain merupakan hasil dari kekuatan penawaran dan permintaan.

Dengan semakin terintegrasinya pasar finansial, mata uang bukan sekedar alat pembayaran, melainkan sudah menjadi komoditas yang sesuai dengan hukum demand dan supply bisa diperjual belikan dengan pelbagai metode dan instrumen. Indonesia sebelum tahun 1978 menganut sistem nilai tukar tetap dan pada periode 1978-1986 berubah mengikuti sistem kurs mengambang terkendali (managed floating system) yang secara teknis sama dengan floating system, tetapi bank Indonesia mempunyai kewenangan untuk mengatur nilai tukar yang dikehendaki. Nilai tukar rupiah dikaitkan dengan sekelompok mata uang asing yang mempunyai bobot tertentu terhadap rupiah dan yang paling dominan adalah nilai tukar rupiah terhadap dolar AS. Pada pertengahan tahun 1996, Indonesia merupakan salah satu negara Asia yang mengalami krisis mata uang yang kemudian disusul dengan suatu krisis ekonomi yang besar.

Menurut Tulus Tambunan dalam bukunya Krisis Ekonomi dan Masa Depan Reformasi (1998:11) menyatakan "Krisis ekonomi kali ini adalah yang paling parah sepanjang Orde Baru. Ditandai dengan merosotnya kurs rupiah terhadap dollar yang luar biasa yang sangat drastis". Menanggapi perkembangan nilai tukar rupiah terhadap dollar AS yang mulai merosot, sejak bulan Mei 1997, pada bulan Juli 1997 Bank Indonesia melakukan intervensi dengan memperlebar rentang intervensi. Tetapi pengaruhnya tidak banyak dan setelah melewati masa krisis akibat tekanan eksternal dan tekanan pasar yang semakin kuat, maka semenjak 14 Agustus 1997 ditempuh kebijakan nilai tukar free floating. Depresiasi yang terus menerus sejak pertengahan tahun 1997 sampai puncaknya pada bulan Mei 1998 mengakibatkan ekonomi mengalami krisis besar. Sektor keuangan dan perbankan nasional hancur, politik sangat tidak stabil dengan jatuhnya kepemimpinan order baru di tambah lagi 
Indonesia sedang terperangkap problem utang luar negeri. Khususnya utang luar negeri swasta yang luar biasa besar, inflasi mencapai angka 2 digit, pertumbuhan ekonomi menunjukkan tanda negatif mengakibatkan terjadinya krisis kepercayaan masyarakat terhadap rupiah, sehingga pemerintah merasa perlu mengkampanyekan gerakan cinta rupiah.

Dengan latar belakang diatas, maka penulis melakukan penelitian dengan judul, "Pengaruh inflasi, tingkat suku bunga SBI dan nilai tukar rupiah terhadap jumlah uang yang beredar di Indonesia. "

\section{Perumusan Masalah}

1. Apakah ada pengaruh yang cukup significant secara statistik antara variabel inflasi, tingkat suku bunga SBI, dan nilai tukar rupiah terhadap jumlah uang yang beredar di Indonesia selama Januari tahun 2001 s/d April tahun 2006.

2. Dari ketiga varibel tersebut di atas manakah yang mempunyai pengaruh dominan terhadap jumlah uang yang beredar di Indonesia selama Januari tahun 2001 s/d April tahun 2006.

\section{Tujuan Penelitian}

1. Untuk mengetahui pengaruh yang cukup significant secara statistik antara variabel inflasi, tingkat suku bunga SBI, dan nilai tukar rupiah terhadap jumlah uang yang beredar di Indonesia selama Januari tahun 2001 s/d April tahun 2006 .

2. Untuk mengetahui pengaruh yang dominan dari ketiga variabel tersebut di atas terhadap jumlah uang yang beredar di Indonesia selama Januari tahun 2001 s/d April tahun 2006.

\section{Ruang Lingkup Penelitian}

Dalam ruang lingkup menunjukkan variabael-variabel yang diteliti. Ruang lingkup dalam penelitian ini terdiri dari dua variable yang meliputi variable bebas $(X)$ dan variable terikat $(Y)$. Yang menjadi variable bebas $(X)$ pada penelitian ini adalah inflasi, tingkat suku bunga SBI dan nilai tukar rupiah. Sedangkan variable terikat $(\mathrm{Y})$ adalah jumlah uang yang beredar.

\section{Definisi Operasional}

1. Tingkat inflasi adalah kecenderungan terjadinya kenaikan harga-harga umum secara terus menerus. Tingkat inflasi yang digunakan adalah tingkat inflasi 
bulanan yang diperoleh dari perhitungan indeks harga konsumen

2. Nilai tukar adalah harga satu unit mata uang asing (Dollar Amerika) dalam mata uang domestic (Rupiah) atau dapat juga dikatakan harga mata uang domestic terhadap mata uang asing

3. Suku bunga SBI adalah suku bunga atas penempatan dana bank pada Bank Indonesia. Suku bunga SBI ini merupakan alat bagi bank Indonesia dalam operasi pasar terbuka. Pergerakan suku bunga SBI akan mempengaruhi jumlah dana bank umum yang ditempatkan di bank Indonesia. Semakin tinggi suku bunga SBI maka akan lebih banyak dana yang akan disalurkan pada bank Indonesia.

4. Jumlah uang beredar adalah mata uang dalam peredaran ditambah dengan uang giral yang dimiliki oleh perseorangan-perseorangan, perusahaan-perusahaan, dan badan-badan pemerintah. Jumlah uang beredar yang terdiri atas uang kartal. uang giral dan uang kuasi disebut dengan jumlah uang beredar dalam arti luas (broad money) dan sering ditulis dengan istilah M2. Dengan demikian, jumlah uang beredar M2 merupakan penjumlah M1 dengan uang kuasi.

\section{Rancangan Penelitian}

Rancangan penelitian diartikan sebagai strategi mengatur latar penelitian agar peneliti memperoleh data yang valid sesuai dengan karakteristik variabel dan tujuan penelitian. Rancangan pada penelitian ini adalah analisis regresi berganda, yang bertujuan untuk mengetahui pengaruh inflasi, tingkat suku bunga SBI dan nilai tukar rupiah terhadap jumlah uang yang beredar

Selanjutnya pada penelitian ini dilakukan pada suatu metode yang berkelanjutan (time series) yang mana tahun 2001 sebagai tahun dasar dan berakhir bulan April tahun 2006, dengan periode pengamatan selama 6 tahun. Variabel yang diangkat dalam penelitian ini adalah inflasi, tingkat suku bunga SBI, dan nilai tukar rupiah sebagai variabel bebas $(\mathrm{X})$ sedangkan variabel terikat $(\mathrm{Y})$ dari penelitian ini adalah jumlah uang yang beredar.

\section{Populasi dan Sampel}

Populasi menurut Arikunto (2002:109) adalah keseluruhan objek penelitian. Dalam penelitian ini yang menjadi populasi adalah jumlah uang yang beredar di Indonesia. Sedangkan sampel menurut Arikunto (2002:109) adalah sebagian atau wakil populasi yang diteliti. Sampel yang digunakan dalam penelitian ini adalah 
tingkat jumlah uang yang beredar di Indonesia selama tahun 2001 sampai dengan bulan April 2006

Sedangkan tehnik sampling yang digunakan dalam penelitian ini adalah purposive sampling yaitu tehnik penentuan sampel dengan pertimbangan tertentu (Sugiyono, 2004:78)

\section{Pengumpulan Data}

Sumber data yang digunakan dalam penelitian ini adalah data sekunder yang diperoleh dari Bank Indonesia yang berupa berupa : inflasi, tingkat suku bunga SBI, nilai tukar rupiah dan jumlah uang yang beredar. Data tingkat inflasi dan tingkat suku bunga SBI dan nilai tukar rupiah diperoleh dari Statistik Ekonomi Keuangan Indonesia dari periode Januari 2001-April 2006.

\section{Analisis Data}

1) Uji Asumsi Klasik

Uji asumsi klasik yang dilakukan ada 3 macam, yaitu uji normalitas, uji multikolinieritas dan uji autokorelasi..

a.Uji Normalitas

Uji normalitas dimaksudkan untuk mengetahui terlebih dahulu apakah semua variabel baik variabel inflasi, tingkat suku bunga SBI dan nilai tukar rupiah terhadap dollar AS serta jumlah uang yang beredar berada pada distribusi normal. Hal ini penting artinya, sebab apabila sebaran variabel itu sendiri sudah tidak berada pada distribusi normal terhadap populasinya. Maka penelitian ini tidak ada artinya bagi pengembangan ilmu.

\section{Uji Normalitas}


One-Sam ple Kolm ogor ov-Sm ir nov Test

\begin{tabular}{|ll|r|r|r|r|}
\hline & & \multicolumn{1}{|c|}{ X1 } & \multicolumn{1}{|c|}{ X2 } & \multicolumn{1}{|c|}{ X3 } & \multicolumn{1}{c|}{$\mathrm{Y}$} \\
\hline $\mathrm{N}$ & & 64 & 64 & 64 & 64 \\
Normal Parameters a,b & Mean & .7041 & 11.7638 & 9351.2969 & 911215.7 \\
& Std. Deviation & .6244 & 3.7542 & 752.6708 & 84178.49 \\
Most Extreme & Absolute & .110 & .155 & .106 & .080 \\
Differences & Positive & .110 & .155 & .106 & .080 \\
& Negative & -.069 & -.118 & -.077 & -.074 \\
Kolmogorov-Smirnov Z & & .880 & 1.241 & .849 & .642 \\
Asymp. Sig. (2-tailed) & & .421 & .092 & .467 & .804 \\
\hline
\end{tabular}

a. Test distribution is Normal.

b. Calculated from data.

\section{Uji Heterokedastisitas}

Correlations

\begin{tabular}{|c|c|c|c|c|c|c|}
\hline & & & $\mathrm{X} 1$ & $\times 2$ & $\times 3$ & $\begin{array}{l}\text { Unstandardiz } \\
\text { ed Residual }\end{array}$ \\
\hline \multirow[t]{12}{*}{ Spearman's rho } & \multirow[t]{3}{*}{$\mathrm{X} 1$} & Correlation Coefficient & 1.000 & .196 & $.372^{\star \star}$ & -.043 \\
\hline & & Sig. (2-tailed) & & .120 & .002 & .736 \\
\hline & & N & 64 & 64 & 64 & 64 \\
\hline & \multirow[t]{3}{*}{$\mathrm{X} 2$} & Correlation Coefficient & .196 & 1.000 & $.382^{* *}$ & .110 \\
\hline & & Sig. (2-tailed) & .120 & . & .002 & .385 \\
\hline & & N & 64 & 64 & 64 & 64 \\
\hline & \multirow[t]{3}{*}{ X3 } & Correlation Coefficient & $.372^{* \star}$ & $.382^{* *}$ & 1.000 & .147 \\
\hline & & Sig. (2-tailed) & .002 & .002 & . & .247 \\
\hline & & $\mathrm{N}$ & 64 & 64 & 64 & 64 \\
\hline & \multirow[t]{3}{*}{ Unstandardized Residual } & Correlation Coefficient & -.043 & .110 & .147 & 1.000 \\
\hline & & Sig. (2-tailed) & .736 & .385 & .247 & \\
\hline & & $\mathrm{N}$ & 64 & 64 & 64 & 64 \\
\hline
\end{tabular}

${ }^{* *}$. Correlation is significant at the .01 level (2-tailed).

\section{Regression}

\section{Model Summary}

\begin{tabular}{|l|r|r|r|r|c|}
\hline Model & $\mathrm{R}$ & R Square & $\begin{array}{c}\text { Adjusted } \\
\text { R Square }\end{array}$ & $\begin{array}{c}\text { Std. Error of } \\
\text { the Estimate }\end{array}$ & $\begin{array}{c}\text { Durbin-W } \\
\text { atson }\end{array}$ \\
\hline 1 & $.883^{\mathrm{a}}$ & .780 & .769 & 40420.4870 & 1.791 \\
\hline
\end{tabular}

a. Predictors: (Constant), X3, X1, X2

b. Dependent Variable: $Y$ 
ANOV A

\begin{tabular}{|c|c|c|c|c|c|c|}
\hline Model & & $\begin{array}{l}\text { Sum of } \\
\text { Squares }\end{array}$ & df & Mean Square & $\mathrm{F}$ & Sig. \\
\hline \multirow[t]{3}{*}{1} & Regression & $3.48 E+11$ & 3 & $1.161 \mathrm{E}+11$ & 71.079 & $.000^{\mathrm{a}}$ \\
\hline & Residual & $9.80 E+10$ & 60 & 1633815770 & & \\
\hline & Total & $4.46 \mathrm{E}+11$ & 63 & & & \\
\hline
\end{tabular}

a. Predictors: (Constant), X3, X1, X2

b. Dependent Variable: $Y$

Coefficients

\begin{tabular}{|c|c|c|c|c|c|c|c|c|c|}
\hline \multirow[b]{2}{*}{ Model } & & \multicolumn{2}{|c|}{$\begin{array}{c}\text { Unstandardized } \\
\text { Coefficients }\end{array}$} & \multirow{2}{*}{$\begin{array}{c}\begin{array}{c}\text { Standardi } \\
\text { zed } \\
\text { Coefficien } \\
\text { ts }\end{array} \\
\text { Beta } \\
\end{array}$} & \multirow[b]{2}{*}{$t$} & \multirow[b]{2}{*}{ Sig. } & \multirow{2}{*}{$\begin{array}{c}\text { Correlatio } \\
\text { ns }\end{array}$} & \multicolumn{2}{|c|}{ Collinearity Statistics } \\
\hline & & $\mathrm{B}$ & Std. Error & & & & & Tolerance & VIF \\
\hline & (Constant) & 763261.8 & 68964.496 & & 11.067 & .000 & & & \\
\hline & $\mathrm{X} 1$ & 30737.086 & 9043.091 & .228 & 3.399 & .001 & .402 & .813 & 1.229 \\
\hline & $\mathrm{X} 2$ & -22375.1 & 1547.215 & -.998 & -14.462 & .000 & -.882 & .769 & 1.301 \\
\hline & $\mathrm{X} 3$ & 41.655 & 8.185 & .372 & 5.089 & .000 & .549 & .683 & 1.463 \\
\hline
\end{tabular}

a. Dependent Variable: $Y$

Dalam rangka uji normalitas terhadap instrumen penelitian ini digunakan formula Kolmogorov-smirnov. Hasil perhitungan Kolmogorov-smirnov baru dapat memiliki makna bilamana hal tersebut dikonsultasikan jika memiliki tingkat signifikan di atas $5 \%$ dikatakan data menyebar normal sedangkan untuk signifikan di atas $1 \%$ data mendekati distribusi normal dan sebaliknya. Untuk mengetahui apakah masingmasing variabel itu berdistribusi normal, dibawah ini akan ditampilkan hasil analisis data sebagai berikut:

1) Data Inflasi

Diperoleh hasil perhitungan kolmogorov-smirnov sebesar 0,880 dengan tingkat signifikansi 0,421 sehingga nilai signifikansinya di atas 5\%. Dengan memperhatikan hasil tersebut dapat dinyatakan bahwa data variabel inflasi berdistribusi normal.

2) Data Tingkat Suku Bunga SBI

Diperoleh hasil perhitungan kolmogorov-smirnov sebesar 1,241 dengan tingkat signifikansi 0,092 sehingga nilai signifikansinya di atas 5\%. Dengan memperhatikan hasil tersebut dapat dinyatakan bahwa data variabel tingkat Suku Bunga Indonesia berdistribusi normal.

3) Data Nilai tukar rupiah terhadap dollar AS

Diperoleh hasil perhitungan kolmogorov-smirnov sebesar 0,849 dengan tingkat signifikansi 0,467 sehingga nilai signifikansinya di atas 5\%. Dengan 
memperhatikan hasil tersebut dapat dinyatakan bahwa data variabel nilai tukar rupiah terhadap dollar AS berdistribusi normal.

4) Data Jumlah Uang Yang Beredar

Diperoleh hasil perhitungan kolmogorov-smirnov sebesar 0,642 dengan tingkat signifikansi 0,804 sehingga nilai signifikansinya di atas 5\%. Dengan memperhatikan hasil tersebut dapat dinyatakan bahwa data variabel jumlah uang yang beredar berdistribusi normal.

b. Persamaan Regresi

Persamaan regresi linier berganda adalah untuk mengetahui pengaruh variabel bebas terhadap variabel terikat sebagai berikut:

$Y=b_{0}+b_{1} X_{1}+b_{2} X_{2}+b_{3} X_{3}$

Dimana:

$\mathrm{Y}=$ Jumlah Uang Yang Beredar

$\mathrm{X}_{1}=$ Inflasi

$\mathrm{X}_{2}=$ Tingkat Suku Bunga SBI

$X_{3}=$ Nilai tukar Rupiah terhadap dollar AS

Berdasar tabel tersebut, ditentukan persamaan bentuk variabel-variabel bebas (X) inflasi, tingkat suku bunga SBI dan nilai tukar rupiah terhadap jumlah uang yang beredar $(\mathrm{Y})$ sebagai berikut:

$Y=763261,8+30737,086 X_{1}-22375,1 X_{2}+41,655 X_{3}$

Dari persamaan regresi linier berganda diatas dapat dianalisis hal-hal sebagai berikut:

bo $=763261,8$ artinya, apabila nilai variabel-variabel inflasi, tingkat suku bunga SBI dan nilai tukar rupiah terhadap dollar AS sama dengan 0, maka jumlah uang yang beredar akan naik sebesar 763261,8 .

$b_{1}=30737,086$ artinya, apabila nilai variabel inflasi naik satu satuan, maka jumlah uang yang beredar akan naik sebesar 30737,086 dengan asumsi variabel bebas yang lain konstan. Hal ini dapat diartikan inflasi yang ada telah memberikan nilai positif dan menaikkan jumlah uang yang beredar.

$b_{2}=-22375,1$ artinya, apabila nilai variabel tingkat suku bunga SBI turun satu satuan, maka variabel jumlah uang yang beredar akan naik sebesar 22375,1 satuan, dengan asumsi variabel bebas yang lain konstan. Hal ini dapat 
diartikan suku bunga Indonesia yang ada telah memberikan nilai negatif dan menurunkan jumlah uang yang beredar.

$\mathrm{b}_{3}=41,655$ artinya, apabila nilai variabel nilai tukar rupiah terhadap dollar AS naik satu satuan, maka jumlah uang yang beredar akan naik sebesar 41,655 dengan asumsi variabel bebas yang lain konstan. Hal ini dapat diartikan nilai tukar rupiah yang ada telah memberikan nilai positif dan menaikkan jumlah uang yang beredar.

c. Uji F

Dari nilai $\mathrm{F}_{\text {hitung }}$ menunjukkan nilai sebesar 71,079 (signifikansi $\mathrm{F}=0,000$ ). Jadi Sig $F<5 \%(0,000<0,05)$ berarti secara bersama-sama variabel inflasi $\left(X_{1}\right)$, tingkat suku bunga SBI $\left(X_{2}\right)$ dan nilai tukar rupiah terhadap dollar AS $\left(X_{3}\right)$ berpengaruh signifikan terhadap variabel jumlah uang yang beredar (Y). Dengan demikian hipotesis yang menduga bahwa ada pengaruh yang signifikan dari variabel inflasi, tingkat suku bunga SBI dan nilai tukar rupiah secara bersamasama terhadap variabel jumlah uang yang beredar terbukti kebenarannya.

Dari nilai $\mathrm{R}$ Square menunjukkan nilai sebesar 0,780 atau 78\%. Artinya bahwa jumlah uang yang beredar $(Y)$ dipengaruhi sebesar $78 \%$ oleh inflasi $(X 1)$ tingkat suku bunga SBI (X2) dan nilai tukar rupiah terhadap Dollar AS sedangkan sisanya $22 \%$ dipengaruhi oleh variabel lain di luar ketiga variabel bebas yang diteliti.

d. Uji $\mathrm{t}$

Uraian pengaruh secara parsial variabel inflasi, tingkat suku bunga SBI dan nilai tukar rupiah terhadap dollar AS adalah sebagai berikut:

1 Variabel inflasi $\left(X_{1}\right)$ nilai $t_{\text {hitung }}$ sebesar 3,399 dengan signifikansi sebesar 0,001. Karena sig $\mathrm{t}>5 \%(0,001<0,05)$ maka secara parsial variabel inflasi $\left(\mathrm{X}_{1}\right)$ berpengaruh signifikan positif terhadap variabel jumlah uang yang beredar $(\mathrm{Y})$ bila variabel bebas lain tetap nilainya.

2 Variabel tingkat suku bunga SBI $\left(X_{2}\right)$ nilai $t_{\text {hitung }}$ sebesar -14,462 dengan probabilitas sebesar 0,000. Karena sig $\mathrm{t}<5 \%(0,000<0,05)$ maka secara parsial variabel tingkat suku bunga SBI $\left(\mathrm{X}_{2}\right)$ berpengaruh signifikan negatif terhadap variabel jumlah uang yang beredar $(Y)$ bila variabel bebas lain tetap nilainya.

3 Variabel nilai tukar rupiah $\left(\mathrm{X}_{3}\right)$ nilai t hitung sebesar 5,089 dengan probabilitas sebesar 0,000 . Karena sig $t<5 \%(0,000<0,05)$ maka secara parsial variabel nilai 
tukar rupiah $\left(\mathrm{X}_{3}\right)$ berpengaruh signifikan positif terhadap variabel jumlah uang yang beredar $(Y)$ bila variabel bebas lain tetap nilainya.

e.Uji Asumsi Multikolinieritas

Multikolinieritas diuji dengan menghitung nilai VIF (Variance Inflating Factor). Bila nilai VIF lebih kecil dari 5 maka tidak terjadi multikolinieritas atau non multikolinieritas (Singgih Santoso, 1999). Hasil pengujian ditunjukkan tabel berikut:

Hasil Uji Asumsi Multikolinieritas

\begin{tabular}{|l|c|l|}
\hline \multicolumn{1}{|c|}{ Variabel bebas } & VIF & Keterangan \\
\hline Inflasi $\left(X_{1}\right)$ & 1,229 & Non multikolinieritas \\
Tingkat Suku Bunga SBI $\left(X_{2}\right)$ & 1,301 & Non multikolinieritas \\
Nilai Tukar Rupiah thd dollar AS $\left(X_{3}\right)$ & 1,463 & Non multikolinieritas \\
\hline
\end{tabular}

\section{f. Uji Asumsi Heterokedastisitas}

Heterokedastisitas diuji dengan menggunakan uji koefisien korelasi Rank Spearman yaitu mengkorelasikan antara absolut residual hasil regresi dengan semua variabel bebas. Bila probabilitas hasil korelasi lebih kecil dari 0,05 (5\%) maka persamaan regresi tersebut mengandung heterokedastisitas dan sebaliknya berarti non heterokedastisitas atau homokedastisitas. Hasil uji heterokedastisitas ditunjukkan pada tabel berikut:

\section{Hasil Uji Asumsi Heteroskedastisitas}

\begin{tabular}{|l|c|c|c|}
\hline \multicolumn{1}{|c|}{ Variabel bebas } & R & P & Keterangan \\
\hline Inflasi $\left(X_{1}\right)$ & $-0,043$ & 0,736 & Homokedastisitas \\
\hline Tingkat Suku Bunga SBI $\left(X_{2}\right)$ & 0,110 & 0,385 & Homokedastisitas \\
\hline $\begin{array}{l}\text { Nilai Tukar Rupiah thd dollar } \\
\text { AS }\left(X_{3}\right)\end{array}$ & 0,147 & 0,247 & Homokedastisitas \\
\hline
\end{tabular}

\section{g.Uji Autokorelasi}

Menguji ada tidaknyakorelasi serial antar residual. Diuji dengan menggunakan Durbin-W atson. 
Diketahui:

$$
\begin{aligned}
\text { Dw } & =1,791 \\
\text { DL } & =1,48 \\
\text { DU } & =1,69 \\
\text { Ho } & =\text { DU }<\text { DW }<4-\text { DU } \\
& =1,69<1,79<4-1,69
\end{aligned}
$$

Berarti tidak ada autokorelasi antar residual

Pengujian secara parsial dari masing-masing variable bebas terhadap variable terikat adalah sebagai berikut:

\section{Hipotesis I}

Berdasarkan table diatas diketahui bahwa dengan nilai $\alpha=0,05$ diperoleh nilai signifikansi $\mathrm{F}$ sebesar 0,000 lebih kecil dari signifikansi $(\alpha=0,05)$. Dan nilai $F_{\text {hitung }}=71,079$, maka Ha yang berbunyi ada pengaruh inflasi, tingkat suku bunga SBI dan nilai tukar rupiah secara simultan berpengaruh terhadap jumlah uang yang beredar diterima. Dari nilai R Square menunjukkan nilai sebesar 0,780 atau 78\% . Artinya bahwa jumlah uang yang beredar (Y) dipengaruhi sebesar 78\% oleh inflasi (X1) tingkat suku bunga SBI (X2) dan nilai tukar rupiah terhadap Dollar AS sedangkan sisanya $22 \%$ dipengaruhi oleh variabel lain di luar ketiga variabel bebas yang diteliti.

\section{Hipotesis II}

Variabel inflasi $\left(X_{1}\right)$ dengan nilai $t_{\text {hitung }}$ sebesar 3,399 signifikansi sebesar 0,000. Karena sig $\mathrm{t}<5 \%(0,001<0,05)$ maka secara parsial variabel inflasi $\left(\mathrm{X}_{1}\right)$ berpengaruh signifikan positif terhadap variabel jumlah uang yang beredar ( $\mathrm{Y}$ ) bila variabel bebas lain tetap nilainya. Berdasarkan tabel diatas variabel tingkat suku bunga SBI $\left(\mathrm{X}_{2}\right)$ nilai thitung sebesar -14,462 signifikansi sebesar 0,000. Karena sig $\mathrm{t}<5 \%(0,001<0,05)$ maka secara parsial variabel tingkat suku bunga SBI $\left(\mathrm{X}_{2}\right)$ berpengaruh signifikan negatif terhadap variabel jumlah uang yang beredar $(Y)$ bila variabel bebas lain tetap nilainya. Berdasarkan tabel diatas diketahui bahwa variabel nilai tukar rupiah $\left(X_{3}\right)$ nilai t hitung sebesar 5,089 dengan probabilitas sebesar 0,000 . Karena sig $t<5 \%(0,000<0,05)$ maka secara parsial variabel nilai tukar rupiah $\left(\mathrm{X}_{3}\right)$ berpengaruh signifikan positif terhadap variabel jumlah uang yang beredar $(\mathrm{Y})$ bila variabel bebas lain tetap nilainya. Dari uji $\mathrm{t}$ diatas maka dapat diketahui bahawa tingkat suku bunga SBI mempunyai pengaruh dominan 
negatif terhadap jumlah uang yang beredar dengan nilai t hitung sebesar -14,462 signifikansi sebesar 0,000 .

\section{HASIL DAN PEMBAHASAN}

\section{Pengaruh Inflasi, Tingkat Suku Bunga SBI dan Nilai Tukar terhadap Jumlah} Uang yang Beredar

Hasil penelitian menunjukkan bahwa dari uji $\mathrm{F}$ hitung menunjukkan nilai sebesar 71,079 (signifikansi $\mathrm{F}=0,000)$ Jadi sig $\mathrm{F}<5 \%(0,000<5 \%)$ berarti secara bersama-sama variabel inflasi, tingkat suku bunga SBI, dan nilai tukar berpengaruh signifikan terhadap jumlah uang yang beredar di Indonesia periode 2001 s/d 2006. Besarnya pengaruh ketiga variabel (inflasi, tingkat suku bunga SBI, dan nilai tukar) terhadap jumlah uang yang beredar terlihat dari angka $\mathrm{R}$ square sebesar $78 \%$, sedangkan sisanya $22 \%$ dapat dijelaskan oleh sebab-sebab yang lain. Naik turunnya inflasi dan jumlah uang yang beredar adalah hal yang menarik untuk dicermati. Berbagai penelitian dilakukan untuk mengetahui apakah dari waktu ke waktu inflasi dapat mempengaruhi jumlah uang yang beredar atau sebaliknya. Menurut teori Monetaris inflasi hanya terjadi akibat gejolak moneter yang diakibatkan oleh pertumbuhan jumlah uang yang beredar, sehingga mengakibatkan naiknya harga akibat tidak seimbangnya jumlah barang dan jumlah uang yang beredar. Dalam teori kuantitas inflasi hanya bisa terjadi kalau ada penambahan volume uang beredar, baik uang kartal maupun uang giral. Inti yang kedua adalah laju inflasi ditentukan oleh laju pertambahan jumlah uang yang beredar dan psikologi atau harapan masyarakat mengenai kenaikan harga-harga di masa datang.

Inflasi akan mendorong tuntutan akan kenaikan upah dan kenaikan upah akan merangsang naiknya harga.. Inflasi akan menimbulkan gangguan terhadap fungsi uang, terutama fungsi tabungan, fungsi pembayaran dimuka, dan fungsi unit perhitungan. Dengan inflasi yang terus meningkat maka akan meningkatkan kecenderungan berbelanja, terutama untuk barang non primer dan mewah. Hal ini akan mengakibatkan jumlah uang yang beredar di masyarakat akan bertambah. Untuk menanggulangi keadaan tersebut maka pemerintah akan berusaha mengurangi jumlah uang yang beredar di masyarakat, salah satu cara yang dilakukan adalah meningkatkan tingkat suku bunga. Tingkat suku bunga yang tinnggi akan menarik masyarakat untuk menyimpan uang dalam tabungan, 
deposito atau membeli sertifikat SBI yang dikeluarkan oleh pemerintah. Masalah yang terus menerus mendapat perhatian pemerintah adalah masalah inflasi. Tujuan pemerintah adalah menjaga agar tingkat inflasi yang berlaku tetap berada pada tingkat yang sangat rendah. Tingkat inflasi nol persen bukan merupakan tujuan utama kebijakan pemerintah karena tingkat inflasi tersebut sukar untuk dicapai. Yang paling penting untuk diusahakan adalah menjaga agar tingkat inflasi tetap rendah. Adakalanya tingkat inflasi meningkat dengan tiba-tiba sebagai akibat suatu peristiwa tertentu yang berlaku di luar ekspektasi pemerintah misalnya efek dari pengurangan nilai uang (depresiasi nilai uang) yang sangat besar atau kestabilan politik. Menghadapi masalah inflasi yang bertambah cepat ini pemerintah akan menyusun langkah-langkah yang bertujuan agar kestabilan harga-harga dapat diwujudkan kembali.

Inflasi yang tinggi tidak akan menggalakkan perkembangan ekonomi. Biaya yang terus menerus naik akan menyebabkan kegiatan produktif sangat tidak menguntungkan. Kenaikan harga-harga menimbulkan efek yang buruk pula pada perdagangan. Kenaikan harga menyebabkan barang-barang negara itu tidak dapat bersaing di pasaran internasional. Maka ekspor akan menurun. Sebaliknya, harga-harga produksi dalam negeri yang semakin tinggi sebagai akibat inflasi menyebabkan barang-barang menjadi relatif murah. Maka akan lebih banyak impor yang akan dilakukan. Ekspor yang menurun dan diikuti pula dengan impor yang bertambah menyebabkan ketidakseimbangan dalam aliran mata uang asing dan akhirnya kedudukan neraca pembayaran akan memburuk. Selain itu menurut Arifin (1998:12) secara teoritis, dengan asumsi Purchasing Power Parity berlaku, inflasi dalam negeri akan mengakibatkan nilai tukar melemah. Selanjutnya, depresiasi itu sendiri juga akan mendorong inflasi karena pass though effect dari barang-barang dan hahan baku impor sehingga biaya produksi juga akan meningkat. Dalam situasi perekonomian kita yang mengalami depresiasi sangat besar. Depresiasi Rupiah mengakibatkan kenaikan sangat besar pada harga barang-barang tradeable dan nontrade able dan dengan demikian inflasi meningkat.

Tingginya laju inflasi IHK pada tahun 2001 disebabkan oleh melemahnya nilai tukar Rupiah. penetapan kebijakan harga dan pendapatan oleh pemerintah serta tingginya ekspentasi masyarakat akan kenaikan inflasi karena rencana penetapan kebijakan penghapusan subsidi BBM untuk industri. Selain itu 
peningkatan juga disebabkan oleh pola musiman yang terkait dengan meningkatnya permintaan sehubungan dengan perayaan hari besar keagamaan dan pergantian tahun.Menguatnya nilai tukar Rupiah menyebabkan posisi inflasi menurun pada tahun 2002. Tetapi faktor musiman seperti meningkatnya permintaan sehubungan dengan perayaan ban besar keagamaan dan pergantian tahun menyebabkan inflasi INK meningkat pada akhir tahun 2002. Pada awal tahun 2003 inflasi mengalami penurunan, hal ini dikarenakan oleh koreksi harga dengan berlalunya hari raya keagamaan dan tahun baru. Tetapi pada bulanbulan berikutnya setelah triwulan 1-2003 inflasi mengalam kenaikan. Kenaikan ini disebabkan oleh naiknya tarif air minum, tarif dasar listrik, biaya pendidikan dan faktor musiman yaitu perayaan hari raya keagamaan dan tahun baru. Perkembangan inflasi selama triwulan I-2004 menunjukkan kecenderungan menurun. Hal ini dikarenakan oleh tekanan inflasi dari sisi eksternal sangat rendah. Hal ini dotandai oleh perkembangan inflasi global terutama negaranegara mitra dagang yang masih cenderung turun. Di sisi eksternal menurunnya tingkat inflasi disebabkan karena tidak terjadi kenaikan barang-barang untuk kelompok strategis seperti listrik. BBM, telepon dan bea cukai.

Namun meningkatnya inflasi dunia juga mempengaruhi kenaikan harga dalam negeri sehingga inflasi meningkat pada pertengahan tahun 2004. Selain itu peningkatan inflasi juga disebabkan oleh kenaikan tarif telepon, penurunan pasokan sejumlah komoditi dan meningkatnya permintaan barang dan jasa sehubungan dengan perayaan hari keagamaan dan libur akhir tahun Kenaikan harga minyak dunia pada tahun 2005 menyebabkan naiknya harga BBM di dalam negeri. Kenaikan harga bahan bakar minyak (BBM) ini akhirnya menimbulkan tekanan pada inflasi. Untuk mengatasi masalah yang ditimbulkan oleh naiknya harga minyak dunia, pemerintah menaikkan harga minyak (BBM) di dalam negeri. Kenaikan ini dimaksudkan agar harga minyak didalam negeri mendekati harga minyak internasional. Selain itu, untuk mengantisipasi kenaikan harga minyak dunia pemerintah mengurangi subsidi BBM karena kenaikan minyak dunia akan menyebabkan meningkatnya suhsidi BBM dan defisit APBN. Jumlah uang beredar merupakan uang beredar yang digunakan dalam aktifitas perekonomian yang berupa uang kartal, uang giral dan uang kuasi.Peningkatan jumlah uang beredar dalam nilai tukar mengambang akan berpengaruh terhadap pendapatan nasional. Karena dengan meningkatnya 
jumlah uang yang beredar, bank-bank memberikan pinjaman lebih banyak sehingga suku bunga turun. Penurunan suku bunga ini berakibat pada meningkat pengeluaran dan sebagian modal lari ke luar negeri. Menurunnya pengeluaran akan membuat neraca perdagangan memburuk sehingga mata uang merosot dan pada akhirnya pengeluaran akan makin meningkat.Salah satu penyebab melemahnya nilai tukar karena upaya para pelaku bisnis di pasar melakukan hedging terhadap posisi utang Dolar mereka dengan membeli Dolar. Dengan membeli Dolar tersebut maka jumlah uang beredar dimasyarakat berubah yaitu jumlah rupiah yang beredar akan bertambah. Oleh sebab itu pemerintah perlu mengeluarkan kebijakan untuk memperketat ruang bagi spekulasi taerhadap mata uang rupiah. Memperketat spekulasi ini bisa dilakukan dengan memperketat transaksi yang bersifat spekulasi di inter-bank.

Nilai tukar secara relative jelas mempengaruhi jumlah uang yang beredar. Baik di dalam dunia internasional maupun di dalam negeri, suatu mata uang akan berkurang nilainya apabila jumlah uang yang beredar lebih banyak. (Lindert, 1995:374). Setiap ada tanda yang menunjukan bahwa jumlah uang yang beredar tumbuh dengan cepat maka pasti mata uang tersebut tersedia dalam jumlah banyak dan nilainya akan merosot. Dengan demikian, masyarakat akan bereaksi dengan cepat terhadap pernyataan dari pejabat bank sentral sebagai akibat dari adanya tekanan politik. Hal ini merupakan suatu alasan mengapa para pejabat bank sentral selalu berbicara dengan sangat hati-hati. Menurut Lindert (1995:365) sepanjang negara-negara memiliki mata uangnya sendiri, maka menganisis nilai tukar atau pembayaran internasional tanpa melihat pada pasar uang nasional seperti bermain hamlet tanpa pangeran Jerman. Perubahan nilai tukar adalah perubahan nisbah harga antara uang suatu negara dengan uang negara lainnya. Dan, penawaran harga yang disebut "valuta asing". termasuk di dalamnya keseluruhan jumlah uang yang beredar dari suatu negara. dan bukan hanya saldo perbankan dari para spesialis mata uang asing yang jumlahnya sedikit itu. Posisi uang beredar khususnya M2 mengalami kenaikan setiap bulannya. Kenaikan ini dikarenakan oleh banyak faktor. Pada awal tahun 2001 kenaikan M2 disebabkan oleh meningkatnya jumlah uang kuasi Rupiah baik pada tabungan maupun deposito dalam Rupiah masing-masing. Selain itu jika dilihat dari komponen-komponen pembentuk M2, peningkatan tersebut lebih disebabkan oleh naiknya simpanan valuta asing masyarakat dan turunnya 
simpanan Rupiah terutama simpanan masyarakat dalam deposito. Pada tahun akhir 2001 tidak selalu terjadi kenaikan terdapat juga penurunan dalam jumlah uang yang beredar. Penurunan ini disebabkan oleh menguatnya nilai tukar Rupiah. Karena penguatan nilai tukar ini menyebabkan turunnya simpanan dalam valuta asing.

Pada awal tahun 2002 perkembangan M2 masih mengalami penurunan. Hal ini disebabkan oleh masih tingginya tingkat inflasi yang mencerminkan menurunnya daya beli masyarakat. Tetapi pada pertengahan tahun kondisi M2 mengalami peningkatan. Walaupun meningkat, namun peningkatan ini merupakan peningkatan yang pertumbuhannya melambat. Hal ini disebabkan oleh peningkatan uang kartal dan tabungan. Jadi peningkatan hanya terfokus pada peningkatan M 1 saja. Pada tahun 2003 pertumbuhan M2 menunjukan pertumbuhan yang positif namun melambat dengan posisi M2 meningkat. Peningkatan ini lebih dikarenakan oleh net ekspansi Rupiah pemerintah dan peningkatan kredit Rupiah. Selain itu peningkatan M2 juga disebabkan oleh kredit Rupiah dan aktiva luar negeri bersih. Perkembangan jumlah uang beredar pada tahun 2004 mengalami penurunan pada awal tahun dan mengalami kenaikan pada periode triwulan-triwulan berikutnya . Penurunan lebih banyak disebabkan oleh proses penciptaan uang disistem perbankan belum optimal. Pada triwulan II dan triwulan-triwulan berikutnya posisi M2 meningkat tapi peningkatan tersebut masih lebih lambat dibandingkan peningkatan Ml. Hal ini dikarenakan penciptaan uang disistem perbankan masih belum optimal. Selain itu pertumbuhan uang kartal dan giral jauh lebuh besar dibanding pertumbuhan uang kuasi. Melambatnya pertumbuhan uang kuasi diindikasikan terutama bersumber dari semakin minimnya insentif penanaman modal di perbankan sehingga mendorong pengalihan portofolio ke pasar saham dan obligasi. Jumlah uang yang beredar mengalami penurunan pada awal tahun 2005 dan mengalami peningkatan pada triwulan-triwulan berikutnya. Penurunan ini lebih disebabkan oleh menurunnya Ml dan koreksi rekening pemerintah yang jauh lebih besar dari ekspansi kredit. Selain itu pada tahun ini juga terjadi peningkatan M2. Peningkatan ini antara lain disebabkan oleh meningkatnya kredit Rupiah terutama modal kerja dan konsumsi. Selain itu peningkatan M2 juga disebabkan oleh kredit luar negeri dengan menggunakan kurs tetap relatif stabil. Jumlah uang yang beredar perlu perlu diawasi peredarannya. Sehingga jumlah 
permintaan terhadap uang dapat dikendalikan. Selain itu suku bunga dapat dinaikan dan investor tertarik untuk menanamkan modalnya di Indonesia. Sehingga nilai mata uang Rupiah menguat dan pendapatan nasional meningkat.

\section{Tingkat Suku Bunga SBI Mempunyai Pengaruh Dominan Terhadap Jumlah} Uang Yang Beredar

Suku bunga dan tingkat pengembalian investasi sangat penting peranan dan pengaruhnya dalam aliran modal. Suku bunga dan tingkat pengembalian investasi yang rendah cenderung akan menyebabkan modal dalam negeri mengalir ke luar negeri. Sedangkan suku bunga dan tingkat pengembalian investasi yang tinggi akan menyebabkan modal luar negeri masuk ke dalam negeri. Apabila lebih banyak modal masuk ke dalam negeri. permintaan atas mata uang dalam negeri akan bertambah sehingga nilai mata uang tersebut juga akan bertambah. Nilai mata uang suatu negara akan merosot apabila lebih banyak modal negara dialirkan ke luar negeri karena suku bunga dan tingkat pengembalian yang lebih tinggi di negara-negara lain. Salah satu faktor eksternal yang mempengaruhi nilai tukar adalah suku bunga Fed Fund Red. Suku-bunga The Fed merupakan suku bunga Amerika yang menjadi sorotan dunia karena perubahan dalam suku bunga ini akan berdampak pada tingkat suku bunga negara lain, termasuk Indonesia. Perbedaan suku bunga (interest rate differential/IRD) antara Indonesia dan Amerika akan berdampak pada keputusan seseorang dalam menyimpan uangnya dalam Rupiah atau dalam Dolar. Apabila suku bunga SBI lebih besar dari suku bunga The Fed dengan selisih yang besar maka orang akan tertarik untuk menyimpan uangnya dalam Rupiah, begitu juga sebaliknya.Menurut Lindert (1995:372) pasar valuta asing tampaknya memang peka terhadap perubahan buku bunga. Kenaikan nilai tukar secara tiba-tiba sering kali tidak mengikuti perubahan dalam (ih-if), yaitu perbedaan antara suku-bunga di dalam negara (ih) dan di luar negeri (if). Tanggapannya seringkali kelihatan sangat segera dan semakin besar. Liputan berita memgenai kenaikan atau penurunun nilai tukar dari hari kehari biasanya menunjuk kepada suku bunga sebagai penyebabnya.

Menurut Madura (2000:91) perubahan dalam suku bunga relatif mempengaruhi investasi dalam sekuritas-sekuritas, yang selanjutnya akan mempengaruhi permintaan dan penawaran permintaan akan Rupiah. Kenaikan tingkat bunga nominal di suatu negara akan berdampak pada meningkatnya 
permintaan akan mata uang negara tersebut. Sehingga akan berakibat pada naiknya nilai tukar negara tersebut. Terkadang dalam rnelakukan sebuah analisis sering menggunakan tingkat bunga rill untuk mengukur dampak perubahan tingkat bunga terhadap kurs mata uang. Tingkat bunga riil dapat dicari dengan mencari selisih antara tingkat bunga nominal dan laju inflasi.Menurut Arifin (1998:8) secara teoritis dalam perekonomian terbuka dengan arus lalu-lintas modal yang bebas peningkatan suku bunga akan memperkuat nilai tukar karena terjadi pemasukan modal dari luar negeri. Perkembangan suku bunga SB1 pada tahun 2001 menunjukan kecenderungan meningkat. Pada awal tahun kecenderungan meningkat lebih disebabkan oleh perbankan cenderung menempatkan dananya untuk waktu yang lebih pendek. Hal ini dikarenakan oleh krisis yang masih berkelanjutan membuat bank-bank merasa lebih aman menyimpan dananya dalam jangka waktu lebih pendek. Selain itu meningkatnya tekanan inflasi juga mempengaruhi peningkatan suku bunga SBI.

Pada tahun 2002 kondisi suku bunga SBI 1bulan mengalami penurunan. Penurunan terjadi pada awal dan pertengahan tahun disebabkan oleh ekspektasi peserta lelang terhadap suku bunga masih terus menerus naik. Selain itu peningkatan juga dikarenakan oleh perubahan persepsi pasar dan disamping kondisi makro yang kurang menguntungkan. Kondisi suku bunga SBI 1 bulan pada tahun 2003 mengalami penurunan. Penurunan ini dimaksudkan agar untuk memberikan sinyal positif kepada para pelaku usaha akan prospek pemulihan ekonomi. Selain itu penurunan suku bunga juga berdampak pada fungsi intermediasi perbankan yang tercermin pada peningkatan pertumbuhan kredit. Pada akhir tahun penurunan disebabkan oleh lag dalam penentuan suku bunga kredit dan upaya perbankan untuk memenhhi target profitabilitas. Pada akhir tiwulan IV- 2003 suku bunga SBI mengalami penurunan yang cukup besar, hal ini karena meningkatnya permintaan oleh masyarakat. Suku bunga SBI mengalami penurunan awal tahun 2004 sampai dengan pada triwulan II-2004. Kondisi ini menyebabkan instrumen moneter relatif belum berubah untuk menjaga momentum perbaikan ekonomi. Pada triwulan III-2004 suku bunga SBI mengalami peningkatan. Peningkatan ini disebabkan oleh perkembangan suku bunga deposito dan kredit menunjukan perkenbangan yang positif. Tekanan inflasi yang terus meningkat menyebabkan suku bunga SBI 1 bulan mengalami peningkatan pada tahun 2005. Selain itu peningkatan tersebut juga disebabkan 
oleh penempatan kebijakan moneter yang cenderung ketat diperkuat dengan upaya untuk memperbaiki struktur suku bunga.Untuk mengatasi masalah ini pemerintah perlu untuk menaikan tingkat suku bunga. Kenaikan tingkat suku bunga akan menyebabkan banyak investor-investor menanamkan modalnva di negeri menyebabkan permintaan atas mata uang tersebut akan bertambah. BI harus menaikan suku bunga SB I untuk menyeimbangkan kenaikan suku bunga The Fed. Karena apabila suku bunga SBI lebih besar dari pada The Fed dengan selisih yang besar, maka seseorang akan tertarik untuk menyimpan uangnya ke dalam Rupiah dari pada Dolar begitu juga sebaliknya.

\section{Kesimpulan}

Penelitian ini bertujuan menganalisis pengaruh inflasi, tingkat suku bunga SBI dan nilai tukar terhadap jumlah uang yang beredar di Indonesia periode 2001 s/d 2006. Masing-masing variabel bebas, yaitu inflasi, tingkat suku bunga SBI dan nilai tukar serta jumlah uang yang beredar diambil pada periode bulanan.

a. Secara simultan inflasi, tingkat suku bunga SBI dan nilai tukar berpengaruh terhadap jumlah uang yang beredar di Indonesia periode 2001s/d 2006

b. Variabel tingkat suku bunga SBI merupakan variabel yang dominan pengaruhnya terhadap jumlah uang yang beredar di Indonesia periode 2001s/d 2006

\section{Saran}

1. Bagi Peneliti selanjutnya :

Sebaiknya menggunakan periode waktu yang lebih lama (>5Tahun) sehingga dapat dihasilkan hasil yang lebih akurat

2. Bagi pihak Manajemen

Untuk lebih memperhatikan perubahan inflasi, tingkat suku bunga SBI, dan nilai tukar dalam menentukan kebijakan perusahaan

3. Bagi investor

Disamping variabel inflasi, tingkat suku bunga SBI, dan nilai tukar hendaknya juga memperhatikan faktor lain dalam pengambilan keputusan, misalnya kondisi politik, keadaan ekonomi dan perubahan kebijakan pemerintah

4. Bagi Pemerintah

Hendaknya harus senantiasa menjaga indikator ekonomi makro seperti inflasi, tingkat suku bunga SBI dan nilai tukar agar senantiasa stabil sehingga investor 
domestik dan asing berkeinginan atau tetap menanamkan modalnya

\section{DAFTAR PUSTAKA}

Arikunto, Suharsimi. 2002. Prosedur Penelitian Suatu Pendekatan Praktek Edisi Revisi Jakarta Rineka Cipta.

Arin, SjamsuL 1998. Efektifitas Kebijakan Suku Dunga Dalam Rangka Stabilitas Rupiah di Masa Krisis . Buletin Ekonomi Moneter dan Perbankan. Volume 1 Nomor 4. Desember 1998. Hal 1-19.

Bank Indonesia. Laporan Tahunan Bank Indonesia, mulai tahun 2001-2006.

Bank Indonesia. Laporan Triwulan Perkembangan Moneter, Sistetn Pemhayaran dan Perbankan, Vol 1-5 no 1-4 mulai tahun 2001-2006.

Bank Indonesia. Statistik Ekonomi Keuangan Indonesia, mulai lahun 2001-2006.

Budi D, Waluyo dan Siswanto, Benny. 1998. Peranan Kebijakan Nilai Tukar dalam Era Deregulasi dan Globalisasi. Buletin Ekonomi Moneter dan Perbankan. Volume 1 Nomor 1. Juli 1998. Hal 85-122.

Hitman, David, K.2003. Manajemen Keuangan Internasional. Jakarta: V I. Indeks Kelompok Gramedia.

Fabozzi, dkk. 1994. Pasar dan Lemhaga Keuangan Buku Sain. Terjemahan oleh Chaerul Djakman. 1999. Jakarta: Salemba Empat.

Goeltom S, Miranda dan Doddy, Zulveri. 1998. Manajemen Nilai Tukar di Indonesia dan Permasalahannya. Buletin Ekonomi Moneter dan Perbankan. Volume 1 Nomor 2. Sepember 1998. hal 69- 72.

Gujarati, Damodar. 2002. Ekonometri Dasar. Terjemahan oleh J. Supranto. Jakarta : Ghalia Indonesia

Hadi, Hamdy. 2001. Valas untuk Manajer (Forex For Managers). Jakarta: Ghalia Indonesia.

Khalwaty, Tajul. 2000. Inflasi dan Solusinya. Jakarta: PT. Gramedia Pusaka Utama.

Kuncoro, Mudrajad, 1996. Manajemen Keuangan Internasional Pengantar Ekonomi dan Bisnis Global Edisi II. Yogyakarta: BPFE.

Lindert, H Peter dan Kindleberger, P Charles. Tanpa tahun. Ekonomi InternasionaL Terjemahan oleh Burhanudin Abdullah. 1995. Jakarta: Erlangga

Madura, Jeff. 1995. Manajemen Keuangan Internasional Edisi IV. Terjemahan oleh Emil Salim. 2000. Jakarta: Erlangga.

Nopirin. 2000. Ekonomi Moneter Buku 1 Edisi ke- 4. Yogyakarta: BPFE

Nopirin. 2000. Ekonomi Moneter Buku 2 Edisi ke- L Yogyakarta: BPFE 
Nugroho, Bhuono Agung. 2005. Strategi Jitu Memilih Metode Statistik Penelitian dengan SPSS. Yogyakarta: Audi

Prapto S, Wibowo.2003. Analisis Pengaruh Variabel-Variabel Makro Ekonomi terhadap Fluktuasi Nilai Tukar Rupiah Tahun 1999-2002. Skripsi tidak diterbitkan. Malang: Universitas Brawijaya.

Prasetyo, Handoko dan Yuliantu Sri. 2000. Dasar-Dasar Manajemen Keuangan Internasional. Yogyakarta: Andi Yogyakarta.

Salvator, Dominick. 1996. Ekonomi Internasional. Terjemahan oleh Ibris Munandar. 1997. Jakarta: Erlangga.

Samuelson A, Paul dan Nordhaus D. Wiliam. 2004. Makro Ekonomi. Jakarta: PT. Media Global Edukasi.

Simonangkir, Iskandar dan Suseno. 2004. Sistem dan Kebijakan Nilai Tukar. Jakarta: Bank Indonesia.

Subagyo. 2002. Bank dan Lembaga Keuangan Lainnva Edisi ke : 2. Jogyakarta:STIE.

Suhendra, Indra. 2003. Pengaruh Faktor Fundamental, Faktor Resiko dan Ekspektasi Nilai Tukar terhadap Nilai Tukar Rupiah Pasca Penerapan Sistem Kurs Mengambang Bebas 14 Agustus 1998. Buletin Ekonomi Moneter dan Perbankan. Volume 6 Nomor 1. Juni 2003. Hal 35-58.

Sukirno, Sadono. 2004. Makroekonomi Teori Pengantar. Jakarta: PT. Raja Grafmdo Perkasa

Suparmono. 2004. Pengantar Ekomonika Makro Teori, Soal dan Penyelesaian. Yogyakarta: YKPN

Susanto, Singgih. 2001. Buku Latihan SPSS Statistik Parametrik. Jakarta: PT Alex Media Komputindo.

*) Indah Yuliana, SE., MM, Dosen Fakultas Ekonomi UIN Malang 